\title{
ANALISIS AKUNTABILITAS PENGELOLAAN ALOKASI DANA DESA DI DESA PANTAI OA KECAMATAN WULANGGITANG KABUPATEN FLORES TIMUR
}

\author{
Yosefena Andia Dekrita ${ }^{1}$, Imelda Vigula Wisang ${ }^{2}$, Theresia \\ Noviyanti Selan Uran ${ }^{3}$ \\ ${ }^{1,2,3}$ Program Studi Manajemen, Fakultas Ekonomi, Universitas \\ Nusa Nipa Maumere \\ Imeldawisang061082@gmail.com
}

\begin{abstract}
Village Fund Allocation is a fund that the district government must allocate for villages originating from the central and regional financial balance funds received from the district, which use 30\% for operational expenditures and $70 \%$ for community empowerment. This study aims to determine the Accountability of Village Fund Allocation Management. The type of research used is qualitative research with a descriptive analysis approach. Data collection techniques used are interviews, documentation, and literature study. The data sources of this research are primary data and secondary data (documents and archives of Pantai Oa village). The data analysis technique in this study begins with the data reduction stage, data presentation, and conclusion. The research results in the coastal village of Oa show that the management of the Village Fund Allocation from the planning, implementation, reporting, administration, and accountability stages is by Permendagri No. 113 of 2014. The Village Government of Pantai Oa has also been accountable to the region by submitting a report on the Realization of the Village Revenue and Expenditure Budget and installing billboards in front of the village office as a form of accountability to the community. Based on the results of this study, the Management of Village Fund Allocation in Pantai Oa Village can be said to be accountable. Suggestions for the village government to continue improving and maintaining the village government's performance in managing the Village Fund Allocation from each stage in the current period.
\end{abstract}

Keywords: Village Fund Allocation, Accountability, coastal, planning 


\section{PENDAHULUAN}

Pengelolaan Alokasi Dana Desa tidak terlepas dari yang namanya proses manejerial yang diantaranya terdapat proses perencanaan, pelaksanaan, pengawasan serta pertanggungjawaban yang diantaranya terdapat penggunaannya. perencanaan dalam pembangunan desa harus tetap diselaraskan dengan perencanaan dari kabupaten atau kota. Pelaksanaan harus sesuai dengan apa yang sebelumnya telah direncanakan dan juga jalannya pembangunan desa harus ada pengawasan dari aparat pemerintah serta masyarakat agar sesuai dengan undang - undang yang telah berlaku yang ditetapkan pemerintah Indonesia.

Pemberian ADD kepada desa, juga dapat dijadikan cerminan terwujudnya good governance, dimana pemerintah dan masyarakat memiliki hubungan erat dan sekaligus meningkatkan partisipasi masyarakat, sehingga mendorong akuntabilitas, transparansi dan responsivitas pemerintahan lokal. Bahwa prinsipprinsip good governance, diantaranya adalah partisipasi masyarakat, tegaknya supermasi hukum, tumbuhnya transparansi yang dibangun atas dasar arus informasi yang bebas dan informasi perlu diakses oleh pihak-pihak yang berkepentingan dan memadai. Berdasarkan peraturan Menteri Desa, pembangunan daerah tertinggal dan Transmigrasi RI No. 21 tahun 2015 dalam pelaksanaan desa tersebut harus terdapat aspek tata pemerintahan yang baik (good governance) salah satu karakteristiknya adalah akuntabilitas.

Akuntabilitas adalah kewajiban pihak pemegang amanah untuk memberikan pertanggungjawaban, menyajikan, melaporkan dan mengungkapkan segala aktifitas dan kegiatan yang menjadi tanggungjawabnya kepada pihak pemberi amanah yang memiliki hak dan wewenang untuk meminta pertanggungjawaban tersebut (Mardiasmo, 2009) Akuntabilitas merupakan pewujud kewajiban seseorang atau unit organisasi untuk mempertanggung-jawabkan pengelolaan dari awal hingga akhir dalam rangka pencapaian tujuan yang telah ditetapkan melalui media pertanggungjawaban secara periodik. dalam hal ini berkaitan dengan 
pengelolaan Alokasi Dana Desa (ADD) di Desa Pantai Oa sendiri. Dalam pengelolaan Alokasi Dana Desa, dituntut untuk menerapkan prinsip Akuntabilitas agar tercapai semua rencana yang telah disusun.

\section{TINJAUAN PUSTAKA}

\subsection{Desa}

Menurut Undang-Undang Nomor 6 Tahun 2014 tentang Desa bahwa Pemerintahan Desa adalah penyelenggaraan urusan pemerintahan dan kepentingan masyarakat setempat dalam sistem pemerintahan Negara Kesatuan Republik Indonesia. Desa memiliki wewenang sesuai yang tertuang dalam Undang-Undang Nomor 6 Tahun 2014 tentang Desa yakni :

a. Kewenangan berdasarkan hak asal usul

b. Kewenangan lokal berskala Desa

c. Kewenangan yang ditugaskan oleh Pemerintah, Pemerintah Daerah Provinsi, atau Pemerintah Daerah Kabupaten atau Kota, dan kewenangan lain yang ditugaskan oleh Pemerintah, Pemerintah Daerah Provinsi, atau Pemerintah Daerah Kabupaten atau Kota sesuai dengan ketentuan peraturan perundang-undangan.

Menurut Sanusi dkk (2014), Alokasi Dana Desa atau ADD merupakan dana yang harus dialokasikan oleh Pemerintah Kabupaten untuk desa, yang bersumber dari bagian dana perimbangan keuangan pusat dan daerah yang diterima dari Kabupaten yang penggunaannya $30 \%$ untuk belanja aparatur dan operasional dan $70 \%$ untuk belanja publik dan pemberdayaan. Menurut peraturan Menteri Dalam Negeri Nomor 37 Tahun 2007 tentang Pedoman Pengelolaan Keuangan Desa pada pasal 18 bahwa Alokasi Dana Desa berasal dari APBD Kabupaten atau Kota yang bersumber dari bagian Dana Perimbangan Keuangan Pusat dan Daerah yang diterima oleh Kabupaten atau Kota untuk Desa paling sedikit $10 \%$ (sepuluh persen).

Menurut Syachbrani (2012) Alokasi Dana Desa (ADD) adalah bagian keuangan desa yang diperoleh dari bagi Hasil pajak daerah dan bagian dari Dana 
Perimbangan Keuangan Pusat dan Daerah yang diterima oleh kabupaten. ADD dalam APBD kabupaten atau kota dianggarkan pada bagian pemerintah desa, dimana mekanisme pencairannya dilakukan secara bertahap atau disesuaikan dengan kemampuan dan kondisi pemerintah daerah.

\subsection{Akuntabilitas}

Menurut Mahmudi (2011) mengartikan akuntabilitas publik sebagai suatu kewajiban pemegang amanah (agent) untuk memberikan pertanggungjawaban, menyajikan, melaporkan, dan mengungkapkan segala aktivitas dan kegiatan yang menjadi tanggung jawabnya kepada pihak pemberi amanah (Principle) yang memiliki hak dan kewenangan untuk meminta pertanggungjawaban tersebut. Sang pemberi amanah memiliki hak dalam melakukan pengawasan dan mengontrol jalannya pengelolaan yang dilakukan oleh aparat yang berwenang sebagai agent agar tujuan yang diharapkan segera tercapai dan juga menanggulangi suatu kejadiaan yang tidak diharapkan seperti kecurangan terhadap pengalokasian dana desa.

Akuntabilitas yang digunakan dalam pengelolaan keuangan publik adalah akuntabilitas finansial. Akuntabilitas finansial merupakan pertanggungjawaban lembaga- lembaga publik untuk menggunakan dana publik (Public money) secara ekonomis, efisien dan efektif tidak ada pemborosan dan kebocoran dana, serta korupsi dan kolusi. Hasil dari akuntabilitas finansial yang baik akan digunakan untuk membuat keputusan yang berkaitan dengan mobilisasi dan alokasi sumber daya serta mengevaluasi eisiensi penggunaan dana. Hasil tersebut dapat digunakan oleh masyarakat umum dan steakholders untuk menilai kinerja pemerintah berdasarkan sasaran tertentu yang telah disepakati sebelumnya.

Akuntabilitas saat ini menjadi salah satu tuntutan bagi pemerintah pusat maupun pemerintah daerah. Maraknya kasus korupsi diberbagai instansi pemerintahan menjadikan alasan utama pentingnya peningkatan pertanggungjawaban dan keterbukaan informasi kepada masyarakat. sebagaimana yang tertera dalam Permendagri No. 113 tahun 2014 tentang pengelolaan keuangan desa bahwa asas-asas pengelolaan keuangan desa itu 
adalah transparan akuntabel, partisipatif, serta dilakukan dengan tertib dan disiplin anggaran.

\section{METODOLOGI PENELITIAN}

Metode yang digunakan dalam penelitian ini ialah metode kualitatif dengan pendekatan analisis deskriptif. Penelitian ini ialah penelitian studi lapangan yang merupakan penelitian yang memfokuskan pada suatu kondisi saat ini dari objek tertentu yang diteliti sesuai dengan fenomena yang terjadi. Maksud dari penelitian ini adalah mencari tahu atas suatu permasalahan mengenai akuntabilitas pengelolaan Alokasi dana desa di Data ini diperoleh melalui wawancara yang diperoleh melalui wawancara kepada pemerintah desa Pantai Oa yang berperan dalam pengelolaan ADD sehingga mendapatkan informasi sesuai data yang akan diteliti.Desa Pantai Oa Kecamatan Wulanggitang Kabupaten Flores Timur. Data sekunder diperoleh melalui arsip, laporan, buku- buku, dokumen yang dimiliki oleh desa Pantai Oa terkait perencanaan pengelolaan keuangan di desa Pantai $\mathrm{Oa}$ (APBDes. RPJMDes dan RKPDes) sesuai dengan Permendagri No 113 tahun 2014 tentang Pengelolaan Keuangan Desa.

Reduksi data, proses data ini dimulai dengan menelaah seluruh data yang tersedia dari berbagai sumber yakni wawancara, observasi dan dokumentasi. Setelah dikaji langkah selanjutnya adalah membuat rangkuman data yang disebut dengan abstraksi yaitu usaha membuat ringkasan yang inti. Penyajian data dilakukan untuk dapat melihat gambaran keseluruhan atau bagian- bagian tertentu dari gambaran keseluruhan. Pada tahap ini peneliti berupaya mengklarifikasikan dan menyajikan data sesuai dengan pokok permasalahan yang dialami. Penarikan kesimpulan dari temuan data di lapangan untuk dapat menggambarkan dan menjelaskan kesimpulan yang memiliki makna teknik verifikasi yakni menamai analisis secara spesifik dan menarik serta menjelaskan kesimpulan. 


\section{HASIL DAN PEMBAHASAN}

\subsection{Data Perencanaan Alokasi Dana Desa (ADD)}

Dalam program perencanaan ADD sesuai dengan perundang- undangan yang sudah ditetapkan dalam Permendagri No.113 Tahun 2014 disusun melalui musyawarah Dusun (Musdus) kemudian pra Musrembangdes dan dilanjutkan dengan Musrembangdes. . Hal ini senada dengan yang telah disampaikan oleh informan sebagai berikut :

"Terkait dengan perencanaan dan pengawasan dalam pengelolaan $A D D$ sebelumnya sumber- sumber anggaran ini yang tercover di anggaran pendapatan dan belanja desa (APBDes) kurang lebih sebuah anggaran ini diatur oleh regulasiregulasi dari undang-undang sampai dengan peraturan menteri dan regulasi turunannya sampai ke peraturan daerah. Jadi, terkait dengan perencanaan Alokasi Dana Desa di setiap tahun anggaran baru, kita sebagai pemerintahan desa selalu melakukan perencanaan pembangunan desa didalamnya meliputi musyawarah dusun setelah hasil dari musyawarah dusun atau Musdus kita dorong lagi ke Pra Musrembangdes setelah itu Musrembangdes atau musyawarah pembangunan desa. Dari poin- poin usulan atau gagasan yang disampaikan oleh masyarakat lalu kita korelasikan dengan dokumen rencana pembangunan jangka menengah desa yang didalamnya kita petahkan klasternya dalam dokumen RKPDes setiap tahun anggarannya"

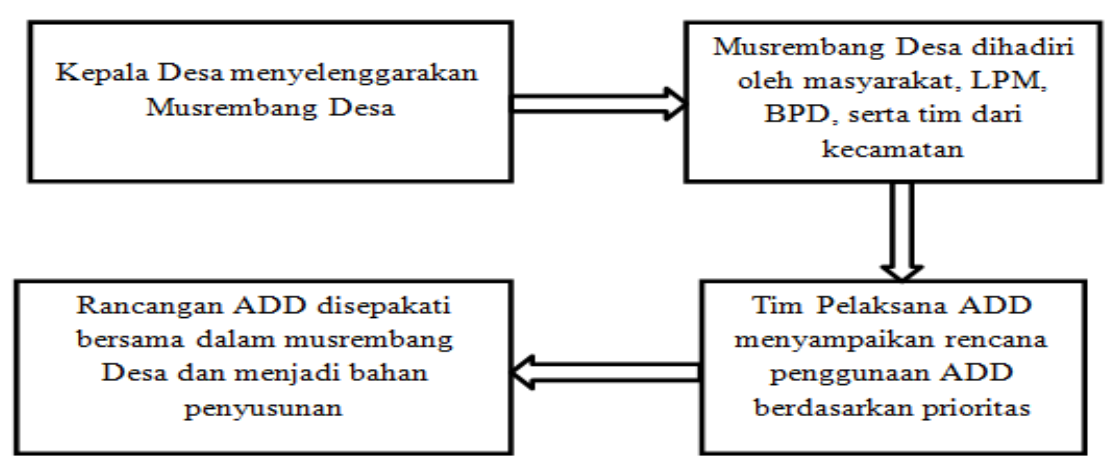

Gambar 1. Mekanisme Perencanaan pengelolaan ADD

Perencanaan Alokasi Dana Desa (ADD) yang dilaksanakan pada Desa 
Pantai Oa sudah memenuhi prinsip pertanggungjawaban yang baik seperti apa yang tertuang dalam Permendagri No. 113 Tahun 2014. Dengan melaksanakan kegiatan Musrembang yang dilihat dari partisipasi masyarakat dalam kegiatan menghadiri kegiatan musrenbang dan berpartisipasi dengan memberikan usulanusulan serta ide atau pendapat. Tingkat partisipasi (kehadiran) dari masyarakat Desa Pantai Oa untuk ikut serta mengambil keputusan dalam pengelolaan penggunaan ADD relatif tinggi yaitu lebih dari $75 \%$ meskipun ada beberapa tokoh masyarakat yang belum sempat hadir untuk memenuhi undangan musrembangdes. namun kehadiran masyarakat sangat mendukung tugas dari pemerintah desa dalam menyusun prioritas pelayanan sehingga bisa melaksanakan kegiatan pengelolaan ADD sesuai dengan kebutuhan masyarakat. Prinsip transparansi sangat dijunjung tinggi oleh pelaksanaan program ADD di Desa Pantai Oa, untuk itu dari tahap perencanaan sampai kegiatan pembangunan diinformasikan secara terbuka. Hasil penelitian ini juga sejalan dengan penelitian terdahulu oleh Irma (2015) dengan judul Analisis Akuntabilitas Pengelolaan Alokasi Dana Desa (ADD) dimana dalam tahap perencanann sudah berjalan dengan baik sesuai dengan permendagri No. 113 Tahun 2014 dimana dalam tahap perencanaan yang baik harus diadakan musrenbangdes untuk menjalankan pembangunan desa melalui usulan- usulan masyarakat yang ada.

\subsection{Akuntabilitas Pelaksanaan, Pertanggungjawaban Alokasi Dana Desa (ADD)}

Dalam melaksanakan program ADD ini, ada beberapa prinsip umum yaitu seluruh penerimaan dan pengeluaran yang dilakukan desa harus melalui rekening kas desa dan kemudian setiap pencairan dana yang dilakukan harus ditandatangani oleh kepala desa serta bendahara desa. Melalui penelitian yang dilakukan dengan teknik wawancara yang sudah dilakukan pada tanggal $\quad 30$ Agustus 2021 Desa Pantai Oa melakukan prinsip pelaksanaan sesuai dengan wawancara berikut :

"Tentu saja kita memiliki rekening kas desa yang dipegang oleh bendahara desa. semua penerimaan dan pengeluaran keuangan desa kami selalu melakukan 
melalui rekening kas desa dan selalu didukung dengan bukti- bukti penerimaan dan pengeluaran yang sah." (Hasil wawancara bersama Bendahara Desa Pada Tanggal 30 Agustus 2021)

Dalam pelaksanaan program ADD ini juga sesuai dengan Permendagri Nomor 113 Tahun 2014 dalam pelaksanaan program ADD dibutuhkan keterbukaan dan prinsip transparansi yaitu dengan adanya Papan informasi yang diisi dengan nama kegiatan, volume, besaran anggaran dari ADD maupun swadaya masyarakat dan jadwal kegiatan fisik yang sementara dan sedang dilaksanakan. Melalui penelitian yang dilakukan dengan teknik wawancara dan observasi lapangan maka ditemukan salah satu wujud akuntabilitas dari tim pelaksana desa di Desa Pantai Oa dalam mendukung keterbukaan informasi pelaksanaan ADD adalah dengan pemasangan pagu APBDes yang tercantumkan nama volume anggaran, besaran anggaran dari dana transfer yang masuk. Keterbukaan informasi ini adalah salah satu kinerja pemerintah desa dalam menerapkan prinsip akuntabilitas dalam pengelolaan anggaran Alokasi Dana Desa.

Pertanggungjawaban pengelolaan Alokasi Dana Desa pada Desa Pantai Oa sudah memenuhi prinsip seperti yang tertuang dalam Permendagri No.113 tahun 2014. Dalam melaksanakan tugas, kewenangan, hak dan kewajibannya dalam pengelolaan keuangan desa dalam hal ini Aloksai Dana Desa (ADD). Kepala desa memiliki kewajiban untuk menyampaikan laporan. Laporan tersebut bersifat periodik semesteran dan tahunan yang disampaikan kepada bupati dan BPD. Pertanggungjawaban Alokasi Dana Desa telah terintegrasi dengan pertanggungjawaban APB Desa.

Pertanggungjawaban ADD di Desa pantai Oa Kecamatan Wulanggitang Kabupaten Flores Timur terintegrasi dengan pertanggungjawaban APBDes. Hal ini sesuai dengan peraturan Bupati No. 19 Tahun 2015 tentang pengelolaan keuangan desa. Peraturan desa tersebut dimaksudkan untuk memberikan landasan hukum bidang keuangan desa, sumber keuangan desa, pengelolaan keuangan desa, dan anggaran pendapatan dan belanja desa. Penguatan keuangan desa dilakukan untuk menguatkan pilar transparansi dan akuntabilitas. 
Pengelolaan keuangan desa harus dilakukan secara eisien dan efektif, transparan dan akuntabel.

\section{KESIMPULAN DAN SARAN}

\subsection{Kesimpulan}

Berdasarkan hasil penelitain dalam pembahasan, maka dapat disimpulkan bahwa akuntabilitas pengelolaan alokasi dana desa pada Desa Pantai Oa Kecamatan Wulanggitang Kabupaten Flores Timur sebagai berikut :

1. Dalam pengelolaan Alokasi Dana Desa di Desa Pantai Oa secara bertahap sudah menerapkan prinsip akuntabilitas yang didukung prinsip transparansi, partisipatif, dan responsive yang terwujud didalam musrengbangdes dengan diikuti kepala desa,perangkat desa, BPD, LPMD, tokoh masyarakat. Dalam pelaksanaan pembangunan mengacu pada skala prioritas, kondisi, situasi masyarakat. Dalam mewujudkan transparansi pengelolaan Alokasi Dana Desa pihak desa Pantai Oa memberikan informasi kepada masyarakat melalui musyawarah desa dan juga melalui pemasangan Baliho di depan Kantor Desa yang memuat informasi Alokasi Dana Desa untuk setiap rancangan program yang dilaksanakan untuk mendukung aktivitas Desa Pantai Oa.

2. Perencanaan program Alokasi Dana Desa telah menerapkan prinsip akuntabel, transparan dan partisipatif dimana perencanaanya dilakukan melalui forum musrembangdes (Musyawarah rencana pembangunan desa). Masyarakat secara terbuka memberikan usulan- usulan dalam perencanaan pembangunan desa yang dituangkan dalam RPJMDes, RKPDes, APBDes dan pemerintah desa pun secara terbuka menerima usul saran dan ditetapkan bersama dengan BPD.

3. Pelaksanannya program Alokasi Dana Desa (ADD) di Desa Pantai Oa bahwa telah Akuntabel. Hal ini dibuktikan dengan hasil wawancara berkaitan dengan Pengelolaan keuangan desa dalam hal ini yang berdasarkan permendagri No.113 Tahun 2014 yang sesuai dengan keadaan pada tahapan pelaksanaan 
Alokasi Dana Desa di Desa Pantai Oa. Pelaksanaan Alokasi Dana Desa telah menerapkan prinsip transparan, akuntabel dan partisipatif dengan melibatkan masyarakat dalam kegiatan terutama pembangunan fisik dan masyarakat juga mengawasi langsung dalam kegiatan pembangunan. selain itu masyarakat dengan mudah mengakses informasi melalui baliho yang dipajang didepan kantor desa.

4. Penatausahaan Pengelolaan Alokasi Dana Desa pada Desa Pantai Oa dilakukan oleh Bendahara Desa dijalankan dengan baik dan sesuai prinsip Akuntabilitas pengelolaan Alokasi Dana Desa berdasarkan Permendagri No. 113 Tahun 2014.

5. Pelaporan dan pertanggungjawaban telah berjalan dengan baik serta menerapkan prinsip transparan, akuntabel dan sudah sesuai dengan Permendagri No.113 Tahun 2014 kepada daerah dan seluruh masyarakat Desa Pantai Oa. Bentuk pertanggungjawaban kepada daerah berupa penyerahan laporan Realisasi APBDes terdiri dari Laporan Realisasi Alokasi Dana Desa Bagi Hasil pajak, Alokasi Dana Desa. Serta kepada masyarakat berupa pemasangan baliho di Depan kantor Desa.

6. Seluruh kegiatan pengelolaan dana ADD baik teknis maupun administratif tidak lepas dari BPD sebagai wakil masyarakat untuk mengevaluasi seluruh kegiatan agar dapat dipertanggungjawabkan sesuai ketentuan yang berlaku.

\subsection{Saran}

Berdasarkan hasil penelitian dan kesimpulan tentang Analisis Pengelolaan Alokasi Dana Desa Pemerintah Desa Pantai Oa, Kecamatan Wulanggitangitang, Kabupaten Flores Timur Tahun 2016 sampai Tahun 2020, maka saran yang dapat peneliti ajukan terkait penelitian ini adalah sebagai berikut:

1. Bagi Pemerintah Desa Pantai Oa untuk tetap meningkatkan dan mempertahankan kinerja yang ada dalam pengelolaan Alokasi Dana Desa setiap periode sepanjang tahun berjalan berdasarkan regulasi atau peraturan yang ada.

2. Pelaksanaan pemerintahaan yang baik perlu adanya akuntabilitas dan 
transparansi dalam pengelolaan alokasi dana desa. Akuntabilitas dan transparansi bermanfaat bagi aparatur desa maupun desa, jika tidak ada akuntabilitas dan transparansi maka inormasi regulasi dan Alokasi Dana Desa hanya diketahui oleh aparat desa. pemerintah yang tidak transparan dan akuntabel akan menimbulkan kecurigaan dan ketidakpercayaan masyarakat terhadap pemerintah desa menyebabkan masyarakat kurang simpati terhadap program desa sehingga program pembangunan desa tidak dapat berjalan.

3. Berkaitan dengan pengarsipan dokumen dalam hal ini Laporan Pertanggungjawaban Alokasi Dana Desa harus disimpan dengan baik agar suatu saat diperlukan mudah untuk ditemukan.

4. Penulis berharap supaya penelitian selanjutnya menambah desa yang dijadikan objek penelitian dengan menambah variabel lainnya.

\section{DAFTAR PUSTAKA}

Anwar, Sanusi. 2014. Metodologi Penelitian Bisnis. Jakarta: Salemba Empat.

Mahmudi. (2011). Akuntansi Sektor Publik. Yogyakarta: UII Press.

Peraturan Bupati Karanganyar Nomor 9 Tahun 2012 tentang Petunjuk Teknis Pengelolaan Anggaran Pendapatan dan Belanja Desa.

Peraturan Menteri Dalam Negeri Nomor 4 Tahun 2007 tentang Pedoman Pengelolaan Kekayaan Desa.

Peraturan Pemerintah Nomor 72 Tahun 2005 Tentang Desa.

Peraturan Menteri Dalam Negeri Nomor 113 Tahun 2014 tentang Pengelolaan Keuangan Desa. (2014).

Syachbrani, Warka. 2012 Akuntansi dan Akuntabilitas Pemerintahan Desa. Tesis: UGM. 